\title{
Role of Calcium in Assembly of the Azotobacter vinelandii Surface Array
}

\author{
By JAMES L. DORAN, WADE H. BINGLE AND WILLIAM J. PAGE* \\ Department of Microbiology, University of Alberta, Edmonton, Alberta, Canada T6G 2E9
}

(Received 25 June 1986; revised 28 August 1986)

\begin{abstract}
Azotobacter vinelandii grown in a defined medium lacking calcium did not exhibit the tetragonally-arranged surface layer present on calcium-sufficient cells, although each cell type possessed equivalent amounts of surface-localized S-protein. The addition of $\mathrm{Ca}^{2+}$ or $\mathrm{Sr}^{2+}$ to calcium-limited cells suspended in buffer resulted in formation of the S-layer, whereas a similar addition of $\mathrm{Mg}^{2+}$ or $\mathrm{Be}^{2+}$ did not. Incubation of cells with ${ }^{35} \mathrm{SO}_{4}^{2-}$ during $\mathrm{Ca}^{2+}$-mediated in vivo reassembly of the S-layer confirmed that the array was formed from previously synthesized, surface-localized S-protein. Rate-zonal sedimentation of S-protein extracted from calciumlimited cells demonstrated tetrameric S-protein subunits characteristic of the native array. Sprotein on the surface of calcium-limited cells was not more susceptible to iodination or proteolytic degradation than that on calcium-sufficient cells. These data suggested minimal alteration of the surface layer beyond disorganization of the S-protein subunits. Calcium limitation caused only a minor perturbation of the outer membrane and did not prevent the outer membrane from serving as a template for the in vitro reassembly of externally supplied S-protein subunits. Notably, $\mathrm{Mg}^{2+}$ or $\mathrm{Ca}^{2+}$ mediated in vitro reassembly of the S-layer and produced a layer that was more loosely attached than the native array. These data support the hypothesis that calcium is specifically required for the in vivo assembly of S-protein subunits into a tetragonal surface array.
\end{abstract}

\section{INTRODUCTION}

Surface layers composed of regularly arranged protein subunits external to the outer membrane are present on many Gram-negative bacteria (Sleytr \& Messner, 1983). Of the five Gram-negative genera studied in any detail, both Azotobacter vinelandii and Aquaspirillum serpens VHA and MW5 require divalent cations for the assembly of their surface layers into regular geometric arrays (Bingle et al., 1984; Buckmire \& Murray, 1976; Kist \& Murray, 1984). The stability of the S-layers of Caulobacter crescentus and Acinetobacter sp. 199A may also be dependent on divalent cations such as $\mathrm{Ca}^{2+}$ and $\mathrm{Mg}^{2+}$ (Smit et al., 1981; Thorne et al., 1975).

The importance of divalent cations to S-layer assembly may be related to the generally acidic nature of proteins constituting the arrays and may be an extension of their general importance in outer membrane structure. The divalent cation requirements of surface arrays are usually gauged by incubating isolated S-layer protein with cations (in the presence of a cell wall template if necessary) followed by electron microscopic examination for evidence of the assembly of the protein into a regular array. This type of experiment has shown that the Acinetobacter sp. 199A and $A z$. vinelandii surface arrays are relatively non-specific with respect to their divalent cation requirements (Bingle et al., 1984; Thorne et al., 1975). In contrast, Aq. serpens MW5 specifically requires $\mathrm{Ca}^{2+}$ for S-layer assembly (Kist \& Murray, 1984), as do other species of Aquaspirillum (Beveridge, 1981). The S-layer of $A q$. serpens VHA will self-assemble in the presence of both $\mathrm{Mg}^{2+}$ and $\mathrm{Ca}^{2+}$ (Buckmire \& Murray, 1976). Significantly, it was shown that the $\mathbf{M g}^{2+}$ reassembled array was susceptible to disruption by distilled water while the $\mathrm{Ca}^{2+}$-reassembled

Abbreviations: DMS, dimethyl suberimate; DTP, 3,3'-dithiobispropionimidate; KDO, 2-keto-3-deoxyoctanoate. 
array and the native array were not. Thus, in vitro reassembly experiments may give misleading results with respect to in vivo assembly requirements unless the stability of the reassembled array can be compared to that of the native array.

We have further investigated the importance of divalent cations, specifically $\mathrm{Ca}^{2+}$ and $\mathrm{Mg}^{2+}$, in the assembly of the $A z$. vinelandii surface layer (Bingle et al., 1984; Page \& Doran, 1981). We report here experiments from which we conclude that $\mathrm{Ca}^{2+}$ is specifically required for the crystallization of S-protein subunits into a tetragonal array.

\section{METHODS}

Bacterial strain and growth conditions. Azotobacter vinelandii UW1 (Fisher \& Brill, 1969) was grown in a potassium-phosphate-based minimal medium (Burk medium) containing $0.6 \mathrm{mM}-\mathrm{CaCl}_{2}, 0.8 \mathrm{mM}-\mathrm{MgSO}_{4}, 18 \mu \mathrm{M}$ $\mathrm{FeSO}_{4}, 1 \mu \mathrm{M}-\mathrm{NaMoO}_{4}, 14 \mathrm{~mm}$-ammonium acetate and $1 \%(\mathrm{w} / \mathrm{v})$ glucose (Bingle et al., 1986). Calcium-limited medium contained all components of calcium-sufficient medium except $\mathrm{CaCl}_{2}$. Water was either glass doubledistilled or treated with the Milli-Q water purification system (Millipore). $\mathrm{BBPO}_{4}$ refers to the potassium phosphate buffer of Burk medium (4.6 mM- $\mathrm{K}_{2} \mathrm{HPO}_{4} / 1.5 \mathrm{mM}-\mathrm{KH}_{2} \mathrm{PO}_{4}, \mathrm{pH} 7 \cdot 2$ ). Cells were pregrown by overnight culture on calcium-limited medium, solidified with $1.8 \%(\mathrm{w} / \mathrm{v})$ agar, before inoculation of calcium-limited liquid medium. Liquid cultures were grown at $30^{\circ} \mathrm{C}$ in a gyratory water bath shaker operating at 175 r.p.m. Analysis of calcium-limited medium by atomic absorption spectroscopy (Greenberg et al., 1985) indicated no detectable $\mathrm{Ca}^{2+}$ in excess of levels present in double-distilled or Milli-Q-treated distilled water $(\leqslant 0 \cdot 35 \mu \mathrm{M})$.

Freeze-etch electron microscopy. In order to expose the Az. vinelandii regular surface array assembled in vivo it was necessary to wash the cells at an elevated temperature before freeze-etching (Bingle et al., 1984). Cells were resuspended to an optical density at $620 \mathrm{~nm}$ of 1 in $\mathrm{BBPO}_{4}$ at $42^{\circ} \mathrm{C}$ and incubated at $42^{\circ} \mathrm{C}$ for $5 \mathrm{~min}$. The cells were collected by centrifugation $\left(1500 \mathrm{~g}, 7 \mathrm{~min}, 21^{\circ} \mathrm{C}\right)$ and the wash treatment was repeated an additional four times. When appropriate, divalent cations $\left(\mathrm{MgCl}_{2}, \mathrm{CaCl}_{2}, \mathrm{BeCl}_{2}\right.$ or $\left.\mathrm{SrCl}_{2}\right)$ were included in $\mathrm{BBPO}_{4}$ at a concentration of $0.5 \mathrm{~mm}$. After washing, the cells were resuspended in residual buffer and processed for freeze-etch electron microscopy as previously described (Bingle et al., 1984). The $42{ }^{\circ} \mathrm{C}$ washing protocol was not necessary when visualizing arrays reassembled in vitro onto the surface of distilled-water-washed cells (Bingle et al., 1984). All freeze-etch experiments were repeated at least twice.

Recovery of protein and lipopolysaccharide (LPS) from distilled water wash fluids, culture supernatants and EDTA or EGTA extracts. Cells were washed with distilled water to remove the surface array by a modification of the filtration method of Schenk \& Earhart (1981) as outlined by Bingle et al. (1984). Distilled water wash fluids and culture supernatants were initially filtered through a $0.45 \mu \mathrm{m}$ pore size Millipore filter. Protein released into these fluids was recovered by ultrafiltration using an Amicon PM10 membrane (molecular mass cut-off $10 \mathrm{kDa}$ ).

LPS was recovered from wash fluids and culture supernatants by lyophilization followed by dialysis against distilled water (molecular mass cut-off $3.5 \mathrm{kDa}$ ). EDTA was added to a concentration of 2 mM to culture supernatants to prevent formation of insoluble calcium phosphate salts during lyophilization. Protein :LPS complexes were released from whole cells that had been washed in 1 vol. $10 \mathrm{mM}-\mathrm{K}^{+}-\mathrm{HEPES}$, pH 7.5, and resuspended in 1 vol. $\mathrm{Na}^{+}$-HEPES/EDTA or EGTA, $\mathrm{pH} 8$, followed by incubation for $1 \mathrm{~h}$ at $30^{\circ} \mathrm{C}$ with slow shaking. The cells were removed by centrifugation $\left(12100 \mathrm{~g}, 10 \mathrm{~min}, 4^{\circ} \mathrm{C}\right)$ and the supernatant was filtered through a $0.8 \mu \mathrm{m}$ pore size Millipore filter before concentration by lyophilization. The concentrated extracts were dialysed (molecular mass cut-off $3.5 \mathrm{kDa}$ ) against distilled water at $4{ }^{\circ} \mathrm{C}$.

Protein was estimated either by the method of Bradford (1976) using bovine gamma globulin as a standard or by a modification of the Lowry method (Markwell et al., 1978) using bovine serum albumin as a standard. The concentration of 2-keto-3-deoxyoctanoate (KDO) was determined by the method of Keleti \& Lederer (1974). In order to determine total cell LPS (as KDO), cells were resuspended in distilled water and broken in a French pressure cell. Before KDO analysis, granules of poly- $\beta$-hydroxybutyrate were removed by low-speed centrifugation $\left(2000 \mathrm{~g}, 20 \mathrm{~min}, 4^{\circ} \mathrm{C}\right)$ and the extract was dialysed (molecular mass cut-off $3.5 \mathrm{kDa}$ ) overnight against 1000 vols distilled water. The absorption spectrum of all thiobarbituric-acid-positive material was compared to that of authentic KDO (Hanson \& Phillips, 1981). All samples containing KDO were analysed by SDS-PAGE and periodic acid-Schiff staining to confirm the presence of LPS. All experiments for the determination of protein or KDO were repeated twice.

Isolation of outer membranes and extraction of S-protein. Cells were disrupted in a French pressure cell and outer membrane fragments were recovered on sucrose gradients essentially according to the method of Page \& von Tigerstrom (1982) with the single modification that Tris buffer was replaced with $10 \mathrm{mM}-\mathrm{K}^{+}-\mathrm{HEPES}, \mathrm{pH} 7 \cdot 5$, to prevent perturbation of the outer membrane (Irvin et al., 1981). The refractive index of the sucrose gradient fractions was determined with an Erma refractometer (Erma Optical Works, Tokyo, Japan). S-protein multimer was extracted from outer membrane fragments as described by Bingle et al. (1986). The proportion of S-protein in tetrameric and monomeric form was determined by rate-zonal centrifugation in linear glycerol gradients $(6-30 \%$, $\mathrm{v} / \mathrm{v}$, glycerol in $10 \mathrm{mM}-\mathrm{K}^{+}-\mathrm{HEPES}, \mathrm{pH} 7 \cdot 5$ ) (Bingle et al., 1986). 
Cross-linking of S-protein. Cell walls were purified on sucrose gradients after disruption of the cells in a French pressure cell as described by Page \& von Tigerstrom (1982). Two modifications were made to this protocol: ironlimited Burk buffer was substituted for Tris/ $\mathrm{HCl}$ buffer and the lysozyme treatment was omitted. Purified cell walls were recovered on a cushion of $72 \%$ sucrose by centrifugation $\left(200000 \mathrm{~g}, 1 \mathrm{~h}, 4^{\circ} \mathrm{C}\right)$ and used directly for cross-linking experiments after adjustment of the protein concentration of the suspension to $5 \mathrm{mg} \mathrm{m}^{-1}$. Free Sprotein multimer $\left(1 \mathrm{mg} \mathrm{ml}^{-1}\right)$ was isolated as described above. Outer membranes were suspended at a concentration of $500 \mu \mathrm{g}$ protein $\mathrm{ml}^{-1}$ for treatment with cross-linking reagents, while free S-protein multimer was treated at a concentration of $100 \mu \mathrm{g} \mathrm{ml}^{-1}$.

The protein cross-linking reagents dimethyl suberimate (DMS) and 3,3'-dithiobispropionimidate (DTP; Pierce Chemical Co.) were freshly prepared in $50 \mathrm{mM} \cdot \mathrm{Na}_{2} \mathrm{HPO}_{4}, \mathrm{pH} 10$, followed by quick readjustment of the $\mathrm{pH}$ to $8 \cdot 8$. Cross-linking reactions using cell wall samples were done in at least $50 \mathrm{mM}-\mathrm{Na}_{2} \mathrm{HPO}_{4}$, while cross-linking of Sprotein samples was done in at least $10 \mathrm{mM}-\mathrm{Na}_{2} \mathrm{PO}_{4}$. All cross-linking reactions were done for $15 \mathrm{~min}$ at $33^{\circ} \mathrm{C}$, at an initial $\mathrm{pH}$ of 8.8 , and were stopped by adding a twofold molar excess of Tris/ $\mathrm{HCl}(\mathrm{pH} 8.8)$. Cross-linked proteins were recovered on ultrafiltration membranes using the Amicon micropartition-ultrafiltration system and resuspended in $62.5 \mathrm{mM}-\mathrm{Tris} / \mathrm{HCl}, \mathrm{pH} 6.8$. SDS was added to $2 \%(\mathrm{w} / \mathrm{v})$ and the cross-linked products were analysed by SDS-PAGE.

Analysis of S-protein conformation. The conformation of S-protein on the surface of cells grown in the presence or absence of calcium was investigated by determining its susceptibility to radioiodination and proteases of differing specificities. The accessibility of tyrosine residues of surface-localized S-protein to radioiodination using Iodogen $(50 \mu \mathrm{g})$ and ${ }^{125} \mathrm{I}\left(0.5 \mu \mathrm{Ci} \mu \mathrm{l}^{-1} ; 18.5 \mathrm{kBq} \mu \mathrm{l}^{-1}\right)$ was examined as described by Bingle et al. (1984) with one modification. After radioiodination, the cells were washed with buffer containing $1 \mathrm{mM}-\mathrm{NaI}$ rather than $25 \mathrm{~mm}$ $\mathrm{NaI}$.

The sensitivity of surface-localized S-protein to the proteases (Sigma) trypsin, Staphylococcus aureus V8 protease and thermolysin was examined. EGTA was added in equimolar amounts to the $\mathrm{Ca}^{2+}$ present in the thermolysin preparation, prior to use. Cells from $1.5 \mathrm{ml}$ of culture were collected by centrifugation using a Fisher model 235 microfuge $\left(3 \mathrm{~min}, 4^{\circ} \mathrm{C}\right)$ and the pellet was resuspended in $1 \mathrm{ml}$ calcium-limited Burk buffer and the appropriate protease was added. The suspension was incubated for $1 \mathrm{~h}$ at $30^{\circ} \mathrm{C}$, after which cells were pelleted again and resuspended in buffer containing the following protease inhibitors: trypsin inhibitor from soybean, $100 \mu \mathrm{g} \mathrm{ml}^{-1}$ (vs trypsin), 0.1 mM-diisopropylfuorophosphate (vs $S$. aureus V8 protease) and $0.1 \mathrm{~mm}-1,10$-phenanthroline (vs thermolysin), and incubated for $1 \mathrm{~h}$. The cells were pelleted again, resuspended in $1 \mathrm{ml} 0.1 \%$ Sarkosyl, and vortexed vigorously for $1 \mathrm{~min}$ at room temperature to extract S-protein from the cell surface. The detergent extract was immediately frozen, lyophilized and the residue resuspended in $100 \mu \mathrm{l}$ distilled water for analysis by SDSPAGE.

Analysis of cell walls and S-protein for $\mathrm{Ca}^{2+}$ and $\mathrm{Mg}^{2+}$ content. Cells were cultivated in calcium-sufficient or calcium-limited medium as described above except that the aeration of the cultures was enhanced by increasing the shaking speed to 300 r.p.m. S-protein multimer was extracted from isolated cell walls (Bingle et al., 1986), collected by centrifugation on an Amicon YMT ultrafiltration membrane and resuspended in deionized, doubledistilled water. The $\mathrm{Ca}^{2+}$ and $\mathrm{Mg}^{2+}$ content of lyophilized distilled-water-extracted cell walls and S-protein was determined by atomic absorption spectroscopy using an Instrument Laboratory aa/ae spectrophotometer 751 , according to Greenberg et al. (1985). Samples of 10-12 mg dry weight of cell walls or 5-7 mg dry weight of Sprotein were digested with $2 \mathrm{ml}$ concentrated $\mathrm{HNO}_{3}$ followed by heating to dryness at $110^{\circ} \mathrm{C}$. The residue was redissolved in $0.5 \mathrm{ml}$ concentrated $\mathrm{HCl}$ and diluted to $10 \mathrm{ml}$ with distilled water. Lanthanum was added to a final concentration of 200 p.p.m. prior to analysis. A control sample containing all reagents was assayed for background $\mathrm{Ca}^{2+}$ and $\mathrm{Mg}^{2+}$ levels.

Electrophoresis. SDS-PAGE was done according to Laemmli $(1970)$ in $7 \%$ or $10 \%(\mathrm{w} / \mathrm{v})$ polyacrylamide gels using apparatus and conditions outlined by Bingle et al. (1984). The following proteins were used as molecular mass standards: phosphorylase $a(94 \mathrm{kDa})$, bovine serum albumin $(68 \mathrm{kDa})$, gamma globulin H-chain $(50 \mathrm{kDa})$ and L-chain $(23.5 \mathrm{kDa})$, ovalbumin $(43 \mathrm{kDa})$ and RNAase $(13.7 \mathrm{kDa})$. Autoradiographs were of wet acrylamide gels exposed to Kodak XOMAT-AR5 film. The molecular masses of cross-linked products were determined using $7 \%$ polyacrylamide gels and the following standards (Sigma): myosin $(205 \mathrm{kDa}), \beta$-galactosidase $(116 \mathrm{kDa})$, phosphorylase $b(97 \cdot 4 \mathrm{kDa})$, bovine serum albumin $(66 \mathrm{kDa})$. Gels were stained for protein and carbohydrate by the method of Fairbanks et al. (1971).

\section{RESULTS}

\section{Freeze-etch electron microscopy of cells grown in calcium-limited medium}

When $A z$. vinelandii grown in calcium-limited medium was examined for the presence of the regular S-layer by freeze-etch electron microscopy, none was evident (Fig. $1 a$ ). Cells grown in the presence of calcium exhibited the typical tetragonal array described previously (Bingle et al., 

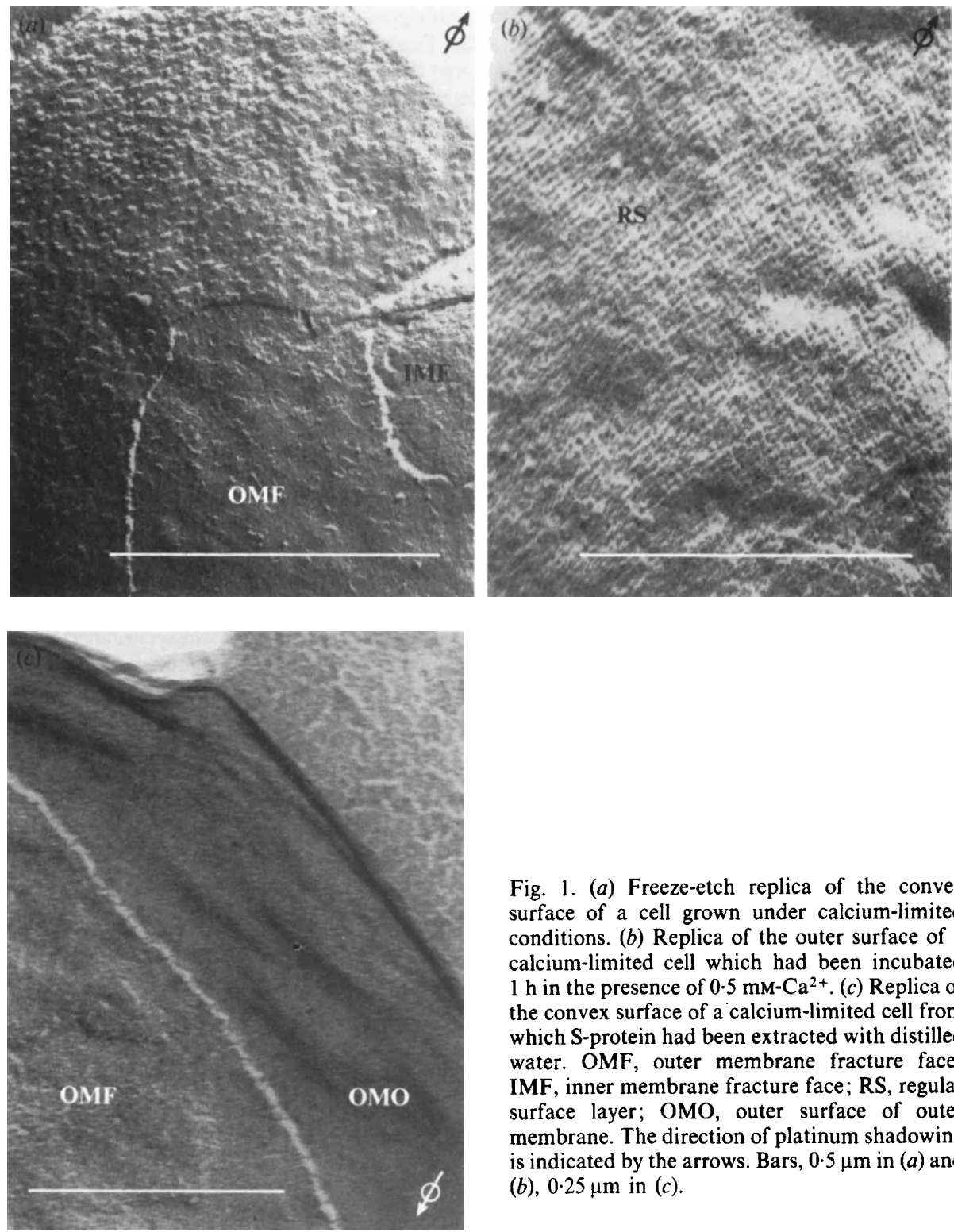

Fig. 1. (a) Freeze-etch replica of the convex surface of a cell grown under calcium-limited conditions. (b) Replica of the outer surface of a calcium-limited cell which had been incubated $1 \mathrm{~h}$ in the presence of $0.5 \mathrm{~mm}-\mathrm{Ca}^{2+}$. (c) Replica of the convex surface of a calcium-limited cell from which S-protein had been extracted with distilled water. OMF, outer membrane fracture face; IMF, inner membrane fracture face; RS, regular surface layer; OMO, outer surface of outer membrane. The direction of platinum shadowing is indicated by the arrows. Bars, $0.5 \mu \mathrm{m}$ in $(a)$ and (b), $0.25 \mu \mathrm{m}$ in (c).

1984). The outer surface of calcium-limited cells exhibited a stippled appearance which was not evident on the outer or inner membrane fracture faces. When a sample of culture was made $0.5 \mathrm{mM}$ with $\mathrm{CaCl}_{2}$ and incubated at $30^{\circ} \mathrm{C}$ for $1 \mathrm{~h}$, the regular array could be found covering the entire cell surface (Fig. 1 b) $\mathrm{Sr}^{2+}$ could substitute for $\mathrm{Ca}^{2+}$, but when $0.5 \mathrm{mM}-\mathrm{MgCl}_{2}$ or $\mathrm{BeCl}_{2}$ was added to the culture the regular array did not reappear. This indicated that the lack of a surface array was not due to a general deficiency of divalent cations but was specifically due to a lack of calcium. These data suggest that formation of the array was not promoted by the $\mathrm{Cl}^{-}$ counter ion. This was confirmed by the observation that $\mathrm{CaSO}_{4}$ also mediated S-layer reassembly on calcium-limited cells (Doran, 1983). After incubation with divalent cations, cells were washed with $\mathrm{BBPO}_{4}$ containing the appropriate cation in order to expose the S-layer (Bingle et al., 1984). To preclude unforeseen artifacts resulting from this washing procedure, the order of the cation addition and washing steps was reversed; identical results were obtained. 


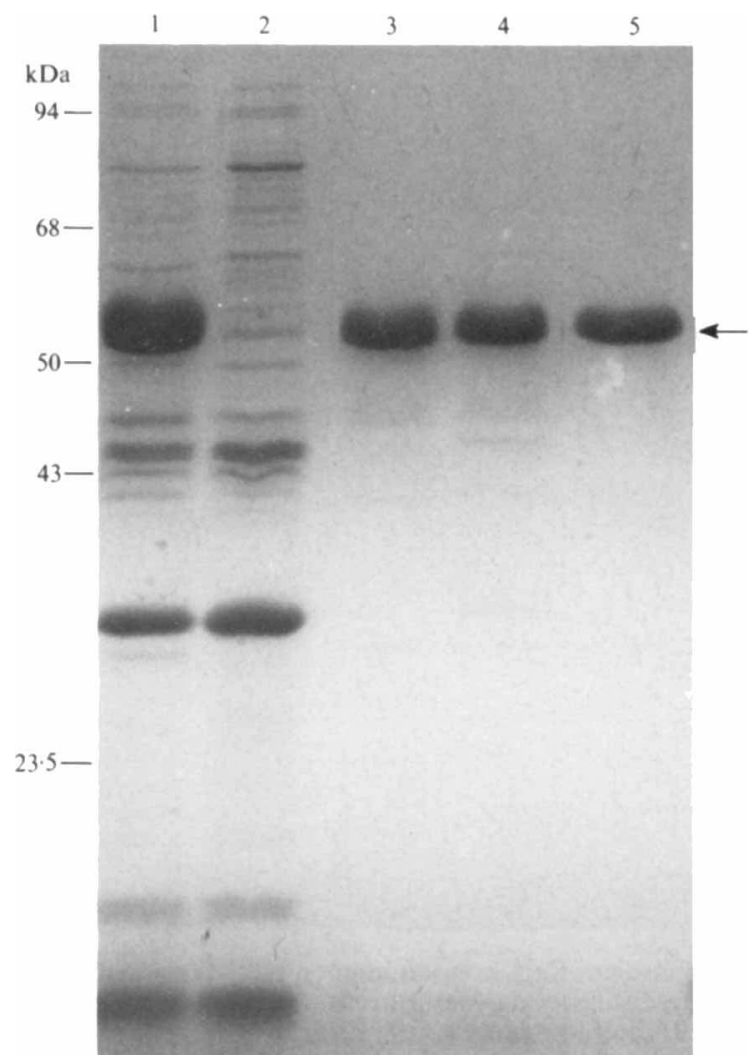

Fig. 2. Release of S-protein from intact calcium-limited $A z$. vinelandii cells by distilled water extraction. Lanes: 1 , outer membrane from unwashed cells; 2 , outer membrane from washed cells; 3 , proteins released into distilled water wash fluids; 4 , concentrated culture supernatant protein from calcium-limited cells; 5 , concentrated culture supernatant protein from calcium-sufficient cells. The arrow indicates the position of the prominent surface protein band in this $10 \%$ polyacrylamide gel.

The $42{ }^{\circ} \mathrm{C}$ heating step in this washing procedure (Bingle et al., 1984) was not necessary in order to visualize by freeze-etch electron microscopy, the regular surface array that was formed upon the addition of $\mathrm{Ca}^{2+}$ to calcium-limited cells (Doran, 1983). This indicated that formation and visualization of the regular array was a $\mathrm{Ca}^{2+}$-dependent, not a heat-dependent, event.

\section{Outer membrane protein profiles of calcium-limited cells}

The possibility that calcium-mediated assembly of the S-layer involved a requirement for de novo synthesis and/or translocation of the nascent S-protein polypeptide to the cell surface was eliminated by examining the polypeptide composition of the outer membranes isolated from calcium-limited cells (Fig. 2, lane 1). These cells possessed S-protein in the outer membrane fraction in amounts normally found with calcium-sufficient cells (Bingle et al., 1984). S-protein was extractable from the outer membrane of intact calcium-limited cells by the relatively mild distilled water-filtration washing method of Schenk \& Earhart (1981) indicating that it was surface localized (Fig. 2, lanes 2 and 3). Examination of distilled-water-washed cells by freezeetch electron microscopy showed that the stippled appearance of the outer surface had been eliminated, producing a relatively smooth surface (Fig. $1 c$ ).

The concentration of calcium in the growth medium influenced the effectiveness of the distilled water extraction of S-protein. Almost complete extraction of S-protein could be reproducibly achieved from cells grown with $<0.5 \mathrm{mM}-\mathrm{CaCl}_{2}$ (Fig. $3 a$, lanes 1-4) while only approximately $50 \%$ of S-protein was released from the outer membrane of cells grown with 


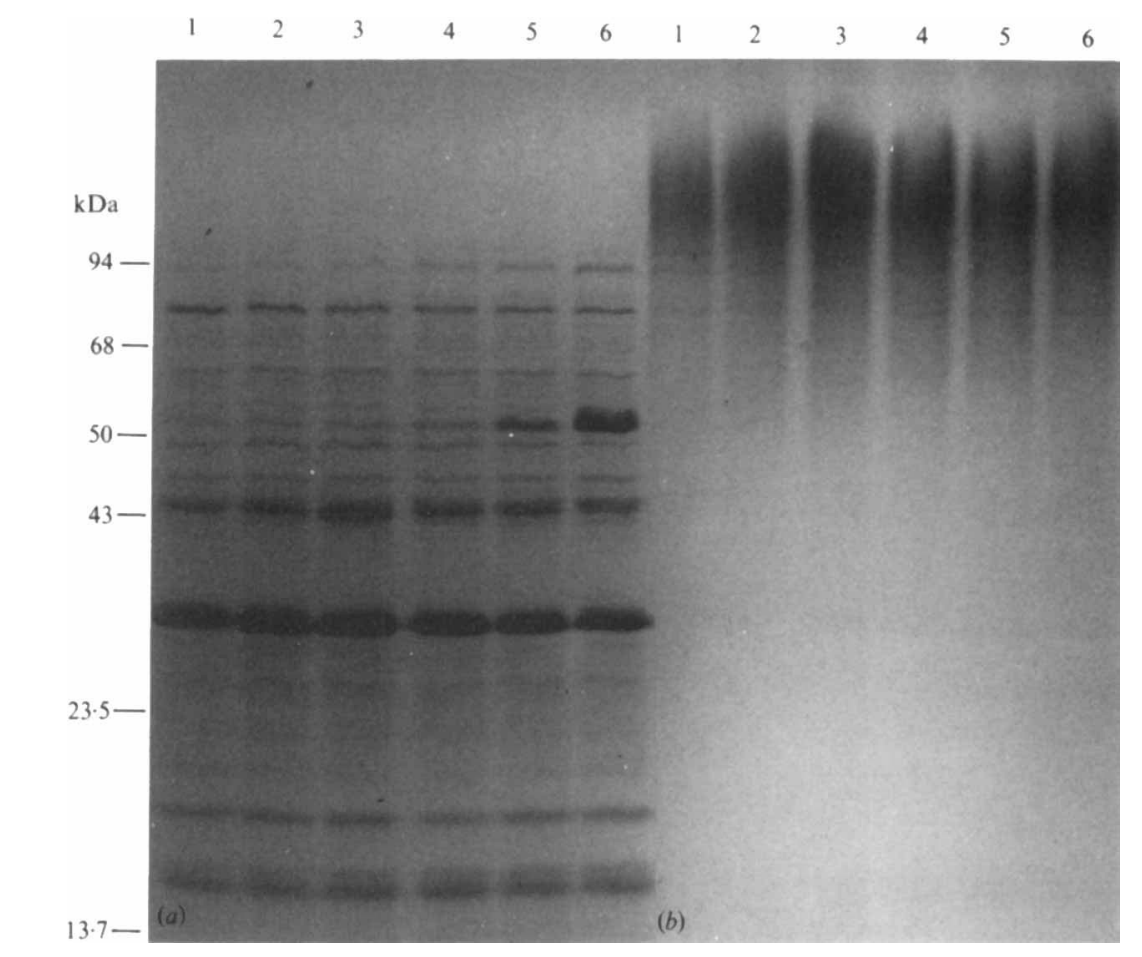

Fig. 3. Effect of growth medium $\mathrm{Ca}^{2+}$ concentration on the protein and LPS composition of outer membranes isolated from distilled-water-washed cells. (a) Coomassie-blue-stained outer membrane proteins separated in a $10 \%$ polyacrylamide gel. (b) Periodic acid-Schiff stain for LPS electrophoresed in the same gel system. Cells were grown in calcium-limited medium (lane 1) or in medium containing $0.1 \mathrm{mM}-\mathrm{Ca}^{2+}$ (lane 2), $0.2 \mathrm{mM}-\mathrm{Ca}^{2+}$ (lane 3 ), $0.3 \mathrm{mM}^{2} \mathrm{Ca}^{2+}$ (lane 4$), 0.5 \mathrm{mM}-\mathrm{Ca}^{2+}$ (lane 5), or $0.7 \mathrm{mM}-$ $\mathrm{Ca}^{2+}($ lane 6).

$>0.5 \mathrm{~mm}-\mathrm{Ca}^{2+}$ (Fig. $3 a$, lane 6). Some variation in the amount of S-protein released by distilledwater washing of cells grown with $0.5 \mathrm{mM}^{-\mathrm{Ca}^{2+}}$ (Fig. $3 a$, lane 5) occurred because of minor variations in $\mathrm{Ca}^{2+}$ concentration in replicate batches of Burk medium, indicating the critical nature of this concentration of $\mathrm{Ca}^{2+}$.

\section{Origin of reassembled S-protein}

The above results suggested that the stippled appearance of the cell surface of calcium-limited cells represented S-protein in an alternative organization and that $\mathrm{Ca}^{2+}$ specifically caused reorganization of S-protein into a regular tetragonal array. In order to confirm this hypothesis, alternative origins for the ordered arrays of S-protein were sought. For example, S-protein released into the culture supernatants could conceivably have reassembled onto the surface of the cells during the incubation with calcium. Culture supernatants from calcium-sufficient and calcium-limited cells were concentrated by ultrafiltration, analysed by SDS-PAGE and the amount of protein in the S-protein band was quantified by densitometry (Bingle et al., 1984). Identical levels of S-protein had been released into these culture fluids. The only protein released into the culture fluids of calcium-sufficient cells was S-protein, which was present at a concentration of $0.8 \mu \mathrm{g} \mathrm{ml}^{-1}$. This amount of S-protein corresponded to $12 \%$ of the total Sprotein that could be removed from an equivalent volume of cells by distilled water extraction (Bingle et al., 1984). Thus there was insufficient S-protein in the culture supernatant to cover the cell with a regular array. Therefore, calcium-mediated assembly of the S-layer was not the result of reattachment of S-protein present in culture fluids. The in vivo reassembly of the S-layer during the incubation of calcium-limited cells in buffer and $\mathrm{Ca}^{2+}$ confirmed this hypothesis. 
Table 1. EDTA- and EGTA-mediated release of protein and LPS from calcium-sufficient and calcium-limited Az. vinelandii

Cells were suspended in $10 \mathrm{~mm}-\mathrm{Na}^{+}$-HEPES, $\mathrm{pH} 8$, and treated as described in Methods. All assays were done in duplicate. $+\mathrm{Ca}^{2+}$ refers to calcium-sufficient cells, and $-\mathrm{Ca}^{2+}$ to calcium-limited cells. Standard deviations are shown in parentheses.

\begin{tabular}{|c|c|c|c|c|}
\hline \multirow[b]{2}{*}{ Treatment } & \multicolumn{2}{|c|}{$\begin{array}{c}\text { Protein released } \\
(\% \text { of total cell protein })\end{array}$} & \multicolumn{2}{|c|}{$\begin{array}{c}\text { LPS released } \\
(\mathrm{KDO} \text { released as } \% \text { of total cell KDO) }\end{array}$} \\
\hline & $+\mathrm{Ca}^{2+}$ & $-\mathrm{Ca}^{2+}$ & $+\mathrm{Ca}^{2+}$ & $-\mathrm{Ca}^{2+}$ \\
\hline $\begin{array}{l}2 \text { mM-EDTA } \\
2 \text { mM-EGTA }\end{array}$ & $\begin{array}{l}4.3(0.7 \%) \\
3.3(0.7 \%)\end{array}$ & $\begin{array}{l}9.8(0.3 \%) \\
1.8(0.1 \%)\end{array}$ & $\begin{array}{l}60(17 \%) \\
54(4.7 \%)\end{array}$ & $\begin{array}{l}53(4.3 \%) \\
23(1.5 \%)\end{array}$ \\
\hline
\end{tabular}

The possibility that the S-layer was formed from newly synthesized S-protein was improbable since $\mathrm{Ca}^{2+}$-mediated assembly in this non-nitrogen-fixing strain of $A$. vinelandii occurred in buffer in the absence of an external nitrogen or carbon source. Further evidence of the lack of significant biosynthesis was obtained when calcium-limited cells were incubated with ${ }^{35} \mathrm{SO}_{4}^{2-}$ ( $1 \mathrm{mCi}$ per $100 \mathrm{ml}$ culture) during $\mathrm{Ca}^{2+}$-mediated assembly of the S-layer in buffer. Considering the quantities of sulphur-containing amino acids in S-protein (Bingle et al., 1986), the proportion of newly synthesized S-protein was estimated to be at most $10 \%$ of the total distilled-waterextractable S-protein. Therefore the majority of S-protein assembled into the regular array was previously synthesized and surface-localized.

\section{Involvement of calcium in outer membrane structure}

Calcium-mediated S-layer formation could have resulted from the interaction of $\mathrm{Ca}^{2+}$ with Sprotein alone or might have involved an effect of $\mathrm{Ca}^{2+}$ on an underlying, putative template layer (outer membrane) or both. The involvement of $\mathrm{Ca}^{2+}$ in outer membrane stability was assessed by incubating cells with 2 mM-EGTA or $2 \mathrm{~mm}$-EDTA and determining the amount of protein and KDO released (Table 1). Calcium-sufficient cells were nearly as sensitive to EGTA as to EDTA, releasing about $90 \%$ of the LPS and $77 \%$ of the protein with EGTA as was released by EDTA. SDS-PAGE of EGTA and EDTA extracts showed that numerous protein species were released (data not shown). Similar extraction of cells osmotically stabilized with $15 \%(\mathrm{w} / \mathrm{v})$ sucrose resulted in a reduced diversity of proteins released, but the profile of proteins released by the two chelating agents appeared identical (Fig. 4, lanes 1 and 2). The presence of LPS and polypeptides of higher molecular mass than S-protein indicated that the protein bands of molecular mass lower than S-protein were unlikely to be degradation products (see Koval \& Murray, 1984).

If $\mathrm{Ca}^{2+}$ stabilized the outer membrane structure, then decreased sensitivity of calcium-limited cells to EGTA due to substitution of $\mathrm{Mg}^{2+}$ for $\mathrm{Ca}^{2+}$ in some sites in the cell wall should be evident (Boggis et al., 1979). This was found to be the case, as indicated by a $50 \%$ reduction of LPS and protein released from calcium-limited cells as compared to calcium-sufficient cells upon treatment with 2 mM-EGTA (Table 1). The effect of EDTA on calcium-limited cells as compared to calcium-sufficient cells was difficult to gauge. Although both types of cells released nearly the same amount of LPS, calcium-limited cells released twice as much protein (Table 1). If the site of attack of EDTA and EGTA was primarily LPS (Hancock, 1984), then extraction of this component apparently caused greater destabilization of the calcium-limited cell envelope.

If $\mathrm{Ca}^{2+}$ were important for envelope integrity, increased levels of both protein and LPS should be evident in culture supernatants of calcium-limited cells. Calcium-limited cells released twice as much protein $\left(1.5 \mu \mathrm{g}\right.$ protein $\left.\mathrm{ml}^{-1}\right)$ as calcium-sufficient cells. Moreover, several minor proteins were found in calcium-limited culture fluids (Fig. 2, lanes 3 and 4) in addition to Sprotein. SDS-PAGE and quantification of S-protein by densitometry indicated that this increase in total supernatant protein was due to the cumulative effect of many minor protein species. No LPS could be detected in calcium-sufficient culture supernatants, while $0.25 \mu \mathrm{g}$ $\mathrm{KDO} \mathrm{ml} \mathrm{m}^{-1}(13 \%$ of total cellular material) was found in calcium-limited culture supernatants. 


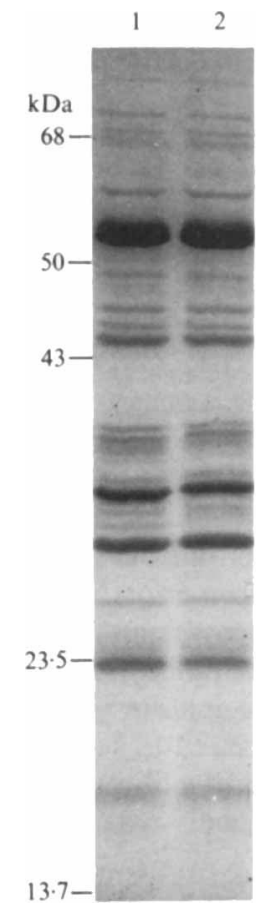

Fig. 4. SDS-PAGE (10\% polyacrylamide) of proteins released from osmotically stabilized (15\% sucrose) calcium-sufficient cells upon treatment with 2 mM-EDTA (lane 1) or 2 mM-EGTA (lane 2) as described in Methods.

Similarly, calcium-limited cells released ten times more KDO $\left[6 \mu \mathrm{g}(\mathrm{mg} \text { protein })^{-1}\right]$ into distilled water wash fluids than did calcium-sufficient cells (Bingle et al., 1984). This level of KDO represented $10 \%$ of the total cellular LPS. The amount of KDO released on washing of calciumlimited cells declined with increased $\mathrm{Ca}^{2+}$ content of the growth medium.

LPS revealed by periodic acid-Schiff staining (Fig. $3 b$ ) was composed of a major highmolecular-mass fraction of limited size heterogeneity similar to that recently reported for Aeromonas salmonicida (Evenberg et al., 1985). Little alteration in the LPS profile of the outer membrane occurred with calcium limitation (Fig. 3b, lanes 1-5). Also, the yield of outer membrane (expressed as protein recovered) from equivalent culture volumes was unaffected by the presence or absence of $\mathrm{Ca}^{2+}$ in the growth medium. Outer membranes isolated from both calcium-sufficient and calcium-limited cells banded at the same position on sucrose gradients (density $1.27 \mathrm{~g} \mathrm{~cm}^{-3}$ ), indicating that the protein :LPS ratios were not significantly different. Omission of $\mathrm{Ca}^{2+}$ from the culture medium did not appear to have any gross effect on the growth of $A z$. vinelandii UW1. Both calcium-sufficient and calcium-limited cultures synthesized the same level of total protein $\left(\approx 200 \mu \mathrm{g} \mathrm{ml}^{-1}\right)$ over the $18-20 \mathrm{~h}$ growth period, although calciumsufficient cultures became slightly iron-limited as evidenced by low production of the siderophore azotobactin (Page \& Huyer, 1984). This was probably due to the formation of $\mathrm{Ca} / \mathrm{Fe}$-phosphate co-precipitates which rendered iron more insoluble. These data indicate that calcium limitation produced somewhat 'leaky' cells, but the gross behaviour of calcium-limited cultures and outer membrane integrity were not seriously compromised. Calcium limitation did not produce an outer membrane incompatible with in vitro organization of the S-protein subunits into a tetragonal array. S-protein subunits isolated from calcium-sufficient cells formed an ordered S-layer when incubated with distilled-water-washed calcium-limited cells and $\mathbf{M g}^{2+}$ in buffer (data not shown). 
In vitro reassembled $S$-layers and their stability

The fact that only $\mathrm{Ca}^{2+}$ (or $\mathrm{Sr}^{2+}$, which possesses somewhat similar chemical properties; Cotton \& Wilkinson, 1980) and not $\mathrm{Mg}^{2+}$ was able to support reassembly of the S-layer when Sprotein was localized on the calcium-limited cell surface in vivo appeared to conflict with the ability of $\mathrm{Ca}^{2+}$ or $\mathrm{Mg}^{2+}$ to promote in vitro reassembly of the S-layer on calcium-limited or calcium-sufficient (Bingle et al., 1984) cells. Previous experiments (Bingle et al., 1984) showed that the native array assembled in vivo was stable to heating at $42^{\circ} \mathrm{C}$ in $5 \mathrm{~mm}$-potassium phosphate buffer. When distilled-water-washed cells carrying $\mathrm{Mg}^{2+}$-mediated reassembled Slayers were treated at $42^{\circ} \mathrm{C}$ in $5 \mathrm{~mm}$-potassium phosphate buffer, $\mathrm{pH} 7 \cdot 2$, for $1 \mathrm{~h}$ no tetragonal array was visible by freeze-etch electron microscopy (data not shown). Concentrated supernatant fluids from cells heated at $42{ }^{\circ} \mathrm{C}$ in $5 \mathrm{~mm}$-potassium phosphate buffer analysed by SDS-PAGE indicated that this treatment released the S-protein from the cell surface. Protein assays confirmed that all of the S-protein that had originally reassembled onto the surface of the distilled-water-washed cells could be recovered in the supernatant fluids after $42^{\circ} \mathrm{C}$ treatment. Therefore, $\mathbf{M g}^{2+}$-mediated reassembly had not returned the layer to its native state.

Surprisingly, when parallel experiments were done with S-layers reassembled in vitro with $\mathrm{Ca}^{2+}$, the S-layer was sensitive to $42^{\circ} \mathrm{C}$ treatment but the in vivo $\mathrm{Ca}^{2+}$-mediated reassembly of the S-layer on calcium-limited cells was stable to $42{ }^{\circ} \mathrm{C}$ treatment. Therefore divalent-cationmediated in vitro reassembly of the $\mathrm{Az}$. vinelandii S-layer appeared to be partially artifactual, and other stabilizing interactions in addition to salt bridging were probably present in the native array assembled in vivo which could not be duplicated when the array was assembled in a manner vectorially opposite to that naturally employed by the cell.

\section{Cross-linking of S-protein}

In order to determine if a close association existed between S-protein of the native array and an outer membrane protein, bifunctional cross-linking reagents were employed. Cross-linking of cell wall proteins with dithiobis(succinimidyl)propionate (DSP; Reithmeier \& Bragg, 1977) resulted in only a minimal reduction (if any) in the S-protein band running in the $55-60 \mathrm{kDa}$ region viewed by SDS-PAGE, indicating minimal cross-linking involving S-protein (data not shown). In contrast, integral outer membrane proteins were cross-linked into high-molecularmass complexes which did not enter the stacking gel (Angus \& Hancock, 1983; Reithmeier \& Bragg, 1977).

Although imidoesters are inferior cross-linking reagents because of their notoriously short half-lives and side reactions (Browne \& Kent, 1975), they are readily soluble. Treatment of isolated cell walls with increasing concentrations of DMS produced an obvious modification of S-protein (Fig. 5a). Even at the lowest concentrations of DMS used, a smearing of the S-protein band in the 55-60 kDa region of the gel was produced. Although DMS concentrations of 1$2 \mathrm{mg} \mathrm{ml}^{-1}$ produced little effect on S-protein beyond an increase in the apparent molecular mass, most integral outer membrane proteins were cross-linked into high-molecular-mass complexes which did not enter the gel. At concentrations of DMS $>5 \mathrm{mg} \mathrm{ml}^{-1}$ a major crosslinked species was produced with an apparent molecular mass of $160 \mathrm{kDa}$ (determined by SDSPAGE in $7 \%$ polyacrylamide gels) concomitant with a loss of S-protein in the 55-60 kDa region of the gel. In an effort to confirm that this cross-linked species was formed from S-protein only, DTP, a cleavable analogue of DMS, was substituted in the reaction mixtures, but the highmolecular-mass cross-linked species could not be generated using this reagent. DMS-mediated cross-linking of cell walls previously extracted with distilled water showed neither the smeared S-protein monomer nor the high-molecular-mass species (Fig. 5a, lane 8). Therefore, the $160 \mathrm{kDa}$ product probably contained S-protein as the only component because cross-linking Sprotein to an integral outer membrane protein would be expected to prevent the complex from entering the gel. Since the S-layer was exposed to excessive concentrations of $\mathrm{Na}^{+}$at high levels of DMS, which may have perturbed its structure, a $\mathrm{Ca}^{2+} /$ triethanolamine buffer system was substituted in the reaction mixtures, but this did not significantly alter the results.

A molecular mass of $160 \mathrm{kDa}$ seemed to indicate that the major product formed was a trimer of S-protein. The cross-linked product expected in the greatest abundance was a dimer of S- 


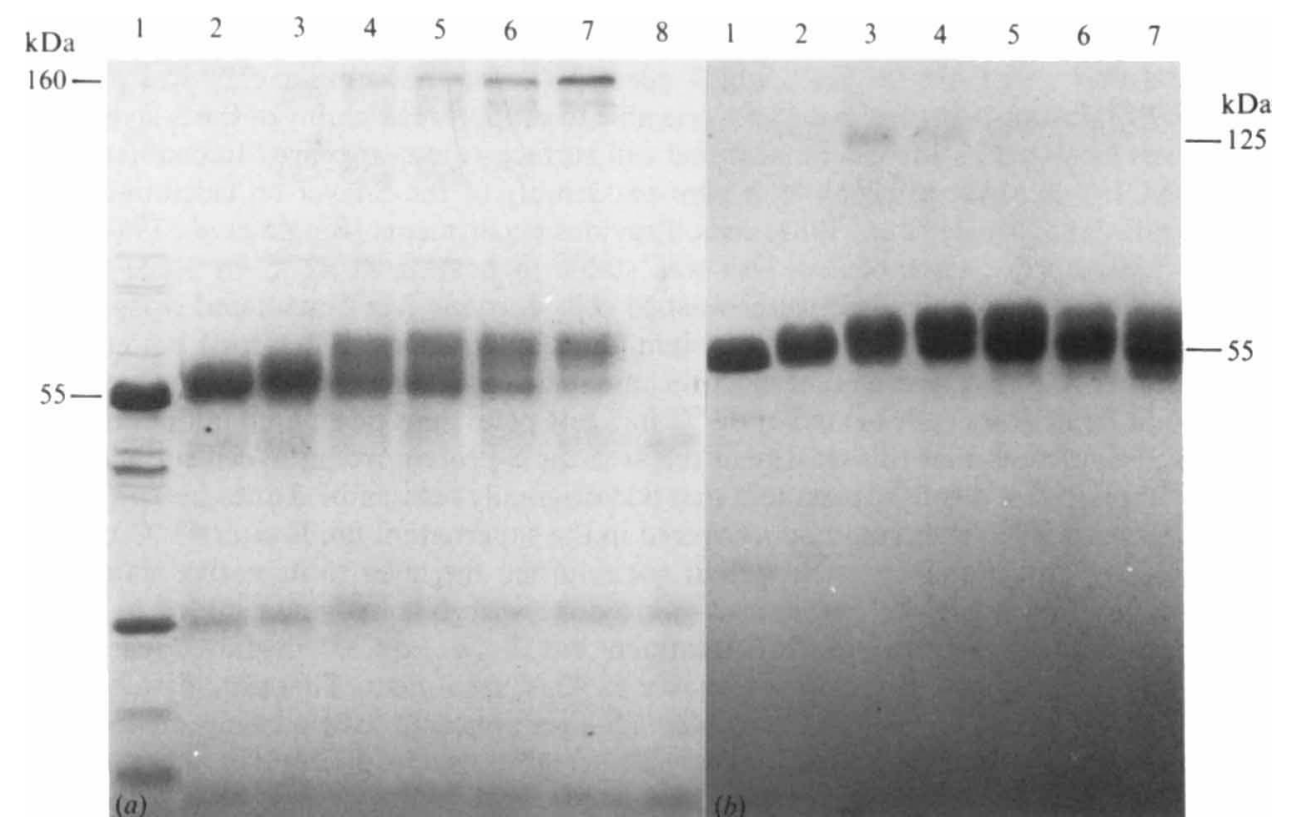

Fig. 5. Cross-linking of $(a)$ cell wall proteins and $(b)$ isolated multimeric S-protein with DMS analysed by SDS-PAGE in $10 \%$ polyacrylamide gels. Concentrations of DMS in samples on gel $(a)$ were lane 1 , $0 \mathrm{mg} \mathrm{ml}^{-1} ; 2,1 \mathrm{mg} \mathrm{ml}^{-1} ; 3,2 \mathrm{mg} \mathrm{ml}^{-1} ; 4,5 \mathrm{mg} \mathrm{ml}^{-1} ; 5,10 \mathrm{mg} \mathrm{ml}^{-1} ; 6,25 \mathrm{mg} \mathrm{ml}^{-1} ; 7,50 \mathrm{mg} \mathrm{m}^{-1} ; 8$, cross-linked distilled-water-washed cell walls with $50 \mathrm{mg} \mathrm{DMS} \mathrm{ml}^{-1}$. Concentrations of DMS on gel $(b)$ were lane $1,0 \mathrm{mg} \mathrm{ml}^{-1} ; 2,0.1 \mathrm{mg} \mathrm{ml}^{-1} ; 3,0.2 \mathrm{mg} \mathrm{ml}^{-1} ; 4,0.5 \mathrm{mg} \mathrm{ml}^{-1} ; 5,1 \mathrm{mg} \mathrm{m}^{-1} ; 6,2 \mathrm{mg} \mathrm{ml}^{-1} ; 7$, $5 \mathrm{mg} \mathrm{mi}^{-1}$.

protein (molecular mass $120 \mathrm{kDa}$ ). However, because of the extensive modification of S-protein at the concentrations of DMS necessary to observe cross-linking, multimeric species were not expected to migrate at the precisely integral multiples of the monomeric molecular mass. Crosslinking of free S-protein multimer with $100-500 \mu \mathrm{g} \mathrm{DMS} \mathrm{ml}^{-1}$ also produced a modification of S-protein seen as a smearing effect in the $55-60 \mathrm{kDa}$ region of the gel as well as a single major cross-linked product (Fig. 5b, lanes 3 and 4). Significantly, the molecular mass of the crosslinked species was estimated at $125 \mathrm{kDa}$, closer to that expected for a dimer of S-protein. This was probably due to a small degree of monofunctional modification as compared to wallassociated S-protein treated at higher DMS concentrations (Fig. 5a). The smearing and product formation could be produced at lower DMS concentrations with free multimer than with Sprotein associated with cell walls, which suggested a difference in accessibility of lysine residues to the cross-linking reagent.

\section{State of S-protein on the surface of calcium-limited cells}

An obvious explanation for the inability of S-protein to organize into a tetragonal array in the absence of calcium was that $\mathrm{Ca}^{2+}$ was required for formation of the morphological subunit of the array. Previous experiments (Bingle et al., 1986, 1987) showed that $\mathrm{Ca}^{2+}$ and $\mathrm{Mg}^{2+}$ stabilized a tetrameric form of S-protein which constitutes the presumed morphological subunit of the array. However, when S-protein was extracted from outer membranes of calcium-limited cells and analysed by rate-zonal centrifugation, the sedimentation profile (not shown) was identical to that of S-protein isolated from calcium-sufficient cells (Bingle et al., 1986). Thus the S-protein on the surface of calcium-limited cells was in a tetrameric form.

To determine whether there were any gross conformational differences between surfacelocalized S-protein from calcium-sufficient and calcium-limited cells, the surface of both cell 

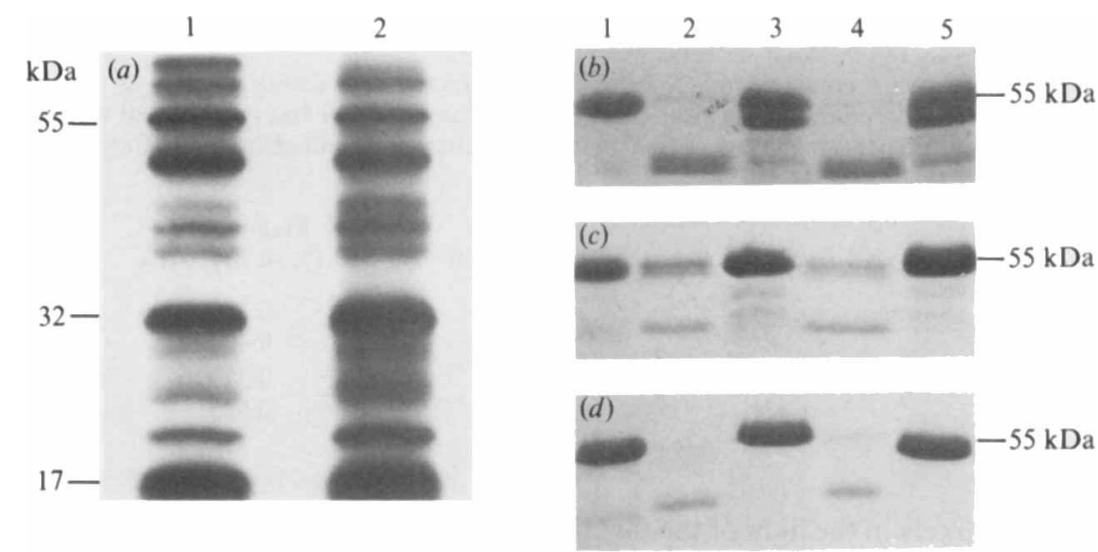

Fig. 6. Analysis of the gross conformation of surface bound S-protein of calcium-sufficient and calcium-limited cells. (a) Autoradiograph of membrane proteins prepared from calcium-sufficient (lane 1) and calcium-limited (lane 2) cells after radioiodination of whole cells. (b-d) SDS-PAGE, in 10\% polyacrylamide gels, of isolated and cell-wall-associated S-protein treated with $(b)$ trypsin $\left(1 \mathrm{mg} \mathrm{ml}^{-1}\right)$, (c) Staphylococcus aureus V8 protease $\left(1 \mathrm{mg} \mathrm{ml}^{-1}\right)$ or $(d)$ thermolysin $\left(1 \mathrm{mg} \mathrm{ml}^{-1}\right)$. Lanes: 1 , untreated Sprotein; 2, S-protein isolated from calcium-limited cells and proteolytically digested; 3, S-protein extracted from calcium-limited cells after proteolytic treatment; 4, S-protein isolated from calciumsufficient cells and proteolytically digested; 5, S-protein extracted from calcium-sufficient cells after proteolytic treatment. Only the relevant portion of the gels, indicating the presence or absence of intact $\mathrm{S}$-protein $(55 \mathrm{kDa})$ after proteolytic treatment, is shown.

types was radioiododinated using ${ }^{125} \mathrm{I}$ and Iodogen. Since S-protein possesses a class of tyrosine residues which are very difficult to label with ${ }^{125}$ I (Bingle et al., 1984) it was reasoned that if a lack of $\mathrm{Ca}^{2+}$ caused any defect in the normal folding of the protein these residues might become more accessible to labelling. However, the cell surface radioiodination patterns of the two cell types were identical (Fig. 6a). Similarly, no differences in the accessibility of S-protein on the surface of calcium-sufficient or calcium-limited cells could be demonstrated using the proteases trypsin, thermolysin and Staphylococcus aureus V8 protease (Fig. $6 b, c, d$ ). No protease at a concentration of 10-100 $\mu \mathrm{g} \mathrm{ml}^{-1}$ had any effect on surface-localized S-protein. Trypsin and $S$. aureus V8 protease at $1 \mathrm{mg} \mathrm{ml}^{-1}$ cleaved surface-localized S-protein although the fragments remained associated with the cell surface until extracted by Sarkosyl. This phenomenon has also been observed for the S-protein of Deinococcus radiodurans (Rachel et al., 1983). In contrast to surface-bound S-protein, all three enzymes caused extensive degradation of soluble S-protein, a difference previously noted for other S-proteins (Sleytr \& Messner, 1983).

\section{$\mathrm{Ca}^{2+}$ and $\mathrm{Mg}^{2+}$ content of cell wall fractions}

Isolated multimeric S-protein and the corresponding distilled-water-extracted cell wall material were analysed for $\mathrm{Ca}^{2+}$ and $\mathrm{Mg}^{2+}$ contents by atomic absorption spectrophotometry (Table 2). Although it might have been expected that S-protein would have been enriched for calcium, the ratio of $\mathrm{Mg}^{2+}$ to $\mathrm{Ca}^{2+}$ in the S-protein fraction was the same as the ratio of these ions in the growth medium. The distilled-water-extracted cell wall also possessed these ions in a similar ratio. The S-protein multimeric subunit fraction accounted for approximately $3 \%$ of the total $\mathrm{Ca}^{2+}$ in the cell wall and approximately $4 \%$ of the total $\mathrm{Mg}^{2+}$. A similar analysis of the cell wall fractions from calcium-limited cells showed a depletion of $\mathrm{Ca}^{2+}$ and an enrichment of $\mathrm{Mg}^{2+}$. The level of $\mathrm{Ca}^{2+}$ in the S-protein and cell wall fractions from calcium-limited cells was $25-30 \%$ of that present in calcium-sufficient cells. Considering the negligible levels of $\mathrm{Ca}^{2+}$ in the growth medium, a much more severe depletion of $\mathrm{Ca}^{2+}$ was expected. The above unexpected observations may be explained if the S-layer serves as a 'cation trap' (Beveridge, 1979), moderating the depletion of $\mathrm{Ca}^{2+}$ during growth in calcium-limited medium and masking any functional enrichment of $\mathrm{Ca}^{2+}$ over $\mathrm{Mg}^{2+}$ during growth in the presence of both cations. This 


\section{Table 2. Calcium and magnesium content of cell wall fractions}

Isolated cell walls were prepared and S-protein was extracted into distilled water as described in Methods. Atomic absorption analysis was carried out on the S-protein and residual cell wall material (outer membrane and peptidoglycan). $+\mathrm{Ca}^{2+}$ refers to calcium-sufficient cells, and $-\mathrm{Ca}^{2+}$ to calciumlimited cells.

$\begin{array}{rcc}\text { Cell wall fraction } & \begin{array}{c}\text { Calcium } \\ (\% \text { of dry wt })\end{array} & \begin{array}{c}\text { Magnesium } \\ (\% \text { of dry wt })\end{array} \\ \text { S-protein }+\mathrm{Ca}^{2+} & 0.276 & 0.224 \\ -\mathrm{Ca}^{2+} & 0.086 & 0.453 \\ \text { Cell wall }+\mathrm{Ca}^{2+} & 0.398 & 0.320 \\ -\mathrm{Ca}^{2+} & 0.095 & 0.635\end{array}$

hypothesis seems likely in the light of the fact that the S-layer has been shown to bind substantial amounts of ferric iron and may serve as a reservoir of iron for Az. vinelandii (Page \& Huyer, 1984). Similarly, the surface layer of Sporosarcina ureae, which apparently demonstrates a $\mathrm{Mg}^{2+}$ requirement in vitro, was found to possess a high content of $\mathrm{Mg}^{2+}$ and no measurable quantities of other cations. However, unlike S-protein from Az. vinelandii, the $S$. ureae preparation was washed in $1 \mathrm{mM}-\mathrm{Mg}^{2+}$ prior to elemental analysis (Beveridge, 1979).

In a final effort to confirm a specific role for $\mathrm{Ca}^{2+}$ in the $A z$. vinelandii $\mathrm{S}$-layer, whole cells were washed five times with $200 \mathrm{mM}-\mathrm{MgCl}_{2}, 10 \mathrm{~mm}-\mathrm{Tris} / \mathrm{HCl}, \mathrm{pH} 8.4$, in an attempt to evoke disorganization at the S-layer by cation displacement (Beveridge, 1979; Beveridge \& Murray, $1976 b$ ). This treatment did not cause disorganization of the $A z$. vinelandii array but, interestingly, it was found to be a most effective method of removing overlying material from the cells (Bingle et al., 1984), thereby providing excellent views of the S-layer by freeze-etch electron microscopy.

\section{DISCUSSION}

Previous studies involving in vitro reassembly of isolated S-protein onto the surface of distilled-water-washed cells indicated that either $\mathrm{Ca}^{2+}$ or $\mathrm{Mg}^{2+}$ could support assembly of the Az. vinelandii S-layer (Bingle et al., 1984). However, the studies reported here indicate that such an approach is at least partially artifactual because reassembly promoted by either cation does not return the S-layer to its native state. Buckmire \& Murray (1976) reported similar findings for the $\mathrm{Mg}^{2+}$-reassembled S-layer of $A q$. serpens $\mathrm{VHA}$; however, $\mathrm{Ca}^{2+}$-mediated reassembly returned this surface layer to its original state and appears to correspond to an absolute requirement for $\mathrm{Ca}^{2+}$ for assembly in vivo (Koval \& Murray, 1985). Similar to calcium-limited $A z$. vinelandii, these cells export $\mathrm{S}$-protein to the cell surface where it subsequently assembles into a surface array when presented with $\mathrm{Ca}^{2+}$. The state of surface-localized S-protein of these organisms differs since that of calcium-limited Aq. serpens is susceptible to loss into culture fluids and by buffer washing. Although calcium-limited $A z$. vinelandii did not release atypical amounts of S-protein into the culture fluids, increased concentrations of $\mathrm{Ca}^{2+}$ in the growth medium did hinder the distilled-water extraction of S-protein from the cell surface.

The inability of $\mathrm{Ca}^{2+}$-mediated in vitro reassembly to promote the formation of a native $\mathrm{S}$ layer on the surface of distilled-water-washed $A z$. vinelandii is surprising considering that when the assembly is performed with S-protein which has been surface localized in vivo, $\mathrm{Ca}^{2+}$ does organize the protein into a regular 'native' array. This suggests that S-protein exported in vivo achieves an association with the outer membrane which cannot be duplicated through the in vitro reassembly process. Cross-linking experiments did not reveal any major close association between S-protein and other outer membrane proteins. In fact, the outer membrane proteins appear to be cross-linked out from under the S-layer. The lack of cross-linking involving Sprotein does not appear to be due to a lack of accessible lysine residues since severe monofunctional modification of S-protein was evident, although it is possible that lysine residues were not suitably disposed for cross-link formation. That cross-linking which did involve S-protein appears to have resulted in the formation of S-protein dimers. Similarly, the S- 
protein of $A q$. serpens VHA also exhibits little tendency to cross-link to other proteins using the reagents employed in this study (Koval \& Murray, 1981).

Although the S-layer of Acinetobacter 199A is believed to associate with an outer membrane protein, evidence exists for an association between the S-layer proteins of Ae. salmonicida (Belland \& Trust, 1985) and $A q$. serpens VHA (Chester \& Murray, 1978) with LPS. It is possible that such an association may exist in $A z$. vinelandii. LPS of Escherichia coli has not been found to participate in DMS-mediated cross-linking reactions (Haller \& Henning, 1974) and for this reason, LPS/S-protein cross-linking may not be detectable in $\mathrm{Az}$. vinelandii. Labischinski et al. (1985), in a recent study of the conformation of LPS, indicated that the O-side chains were not present in an extended conformation but were coiled. In vivo export or assembly of the S-layer may be linked to that of LPS (Thorne et al., 1976). However, during in vitro reassembly with preformed subunits, LPS molecules may prevent access of the subunits to their normal position. This should not prevent reassembly of the $A z$. vinelandii S-protein into a regular array since this organization is apparently determined by the protein subunits themselves (Bingle et al., 1984, 1986).

Clearly, S-protein which has become surface localized in vivo demonstrates a specific requirement for $\mathrm{Ca}^{2+}$ ions for crystallization into a tetragonal array which is not observed when the S-protein has become bound to the cell surface in vitro (Bingle et al., 1984, 1986). This specificity occurs during the organization of preformed S-protein tetramers (Bingle et al., 1986, 1987) into morphological subunits which form the regular array. The presence of tetramers in calcium-limited cells is supported by the similar conformation of S-protein bound to calciumlimited and calcium-sufficient cells as judged by cell surface iodination and proteolytic treatment of whole cells. These results are consistent with previous results which have shown that S-protein monomers (Bingle et al., 1986) and S-protein tetramers (Bingle et al., 1987) do not undergo any gross conformational changes in response to $\mathrm{Ca}^{2+}$, as measured by circular dichroism. It should be emphasized that reassembly both in vivo using calcium-limited cells and in vitro using isolated S-protein and distilled-water-washed cells has only been demonstrated with preformed tetramers of S-protein in Az. vinelandii. Monomeric S-protein has not been demonstrated to reassemble into a regular array (Bingle et al., 1986).

The actual mechanism of regular array formation from unorganized S-protein is a matter of speculation. A reversible transition between organized and unorganized surface bound Sprotein molecules has been observed with $A q$. serpens VHA (Koval \& Murray, 1983), Bacillus sphaericus (Hastie \& Brinton, 1979), Clostridium thermohydrosulfuricum and Clostridium thermosaccharolyticum (Sleytr \& Glauert, 1976). In these cases the regular pattern was destroyed by acidification and could be restored by raising the $\mathrm{pH}$. However, the reduction in $\mathrm{pH}$ probably causes considerable alteration to the folding of the protein (Baumeister et al., 1982).

Koval \& Murray (1985) proposed that for $A q$. serpens $\mathrm{VHA}, \mathrm{Ca}^{2+}$ was required to induce a conformational change in the S-protein to allow crystallization of the surface array. Aquaspirillum putridiconchylium also possesses no visible S-layer when grown in the absence of $\mathrm{Ca}^{2+}$ (Beveridge \& Murray, 1976a). The effect of $\mathrm{Ca}^{2+}$ on the $\mathrm{Az}$. vinelandii S-protein subunits may be as subtle as the $\mathrm{Ca}^{2+}$-induced alteration in the regularly arranged gap junction protein from eukaryotic cells (Unwin \& Ennis, 1984) which would not be detected by the methods used here. S-protein molecules concentrated on the cell surface and suitably oriented to interact to form a crystalline array would conceivably do so provided that the S-protein subunits are sufficiently mobile (Uzgiris \& Kornberg, 1983). An association of S-protein subunits with a diffusible outer membrane component could provide both orientation and mobility.

This study has demonstrated the absolute requirement for $\mathrm{Ca}^{2+}$ for the crystallization of the Slayer of $A z$. vinelandii. In this respect $A z$. vinelandii can be considered similar to Aquaspirillum spp. This study confirms the necessity of testing whether cation-mediated in vitro reassembly experiments using isolated S-proteins yield biologically relevant information. For example, the S-layer of Acinetobacter sp. 199A (Thorne et al., 1975) has been noted by Buckmire \& Murray (1976) to possess curious ionic requirements for reassembly which has led to some confusion in the literature. Beveridge (1981) stated that $\mathrm{Mg}^{2+}$ was required for reassembly while Koval \& Murray (1984) reported that $\mathrm{Cl}^{-}$was required. The latter authors more correctly state the case. 
In fact, either $\mathrm{Na}^{+}, \mathrm{Mg}^{2+}$ or $\mathrm{Ca}^{2+}$ will support in vitro self-assembly of this S-layer as long as the companion anion is $\mathrm{Cl}^{-}$. Other physiologically relevant anions such as $\mathrm{SO}_{4}^{2-}$ and $\mathrm{PO}_{4}^{3-}$ inhibit self-assembly (Thorne et al., 1975). However, the $\mathrm{Cl}^{-}$ion requirement is negated when a cell wall template is provided. These data suggest that, as with $A z$. vinelandii, in vitro S-layer reassembly studies are not providing correct information on the in vivo assembly process.

This study was made possible by a Natural Sciences and Engineering Research Council of Canada operating grant to W. J.P. We thank Park Yee of the Department of Soil Science, University of Alberta, for performing the atomic absorption analyses. J.L.D. was supported by a postdoctoral fellowship from the Alberta Heritage Foundation for Medical Research (AHFMR) and W.H.B. was funded by an AHFMR studentship.

\section{REFERENCES}

ANgus, B. L. \& Hancock, R. E. W. (1983). Outer membrane porin proteins F, P, and D1 of Pseudomonas aeruginosa and PhoE of Escherichia coli: chemical cross-linking to reveal native oligomers. Journal of Bacteriology 155, 1042-1051.

Baumeister, W., KarRenberg, F., Rachel, R., Engel, A., Ten Heggeler, B. \& Saxton, W. O. (1982). The major cell envelope protein of Micrococcus radiodurans $(\mathrm{Rl})$ : structural and chemical characterization. European Journal of Biochemistry 125, 535-544.

Belland, R. J. \& Trust, T. J. (1985). Synthesis, export and assembly of Aeromonas salmonicida A-layer analyzed by transposon mutagenesis. Journal of Bacteriology 163, 877-881.

BEVERIDGE, T. J. (1979). Surface arrays on the wall of Sporocarcina ureae. Journal of Bacteriology 139, 1039-1048.

BEVERIDGE, T. J. (1981). Ultrastructure, chemistry and function of the bacterial wall. International Review of Cytology 72, 229-317.

Beveridge, T. J. \& Murray, R. G. E. (1976a). Dependence of the superficial layers of Spirillum putridiconchylium on $\mathrm{Ca}^{2+}$ or $\mathrm{Sr}^{2+}$. Canadian Journal of Microbiology 22, 1233-1244.

Beveridge, T. J. \& Murray, R. G. E. (1976 b). Reassembly in vitro of the superficial cell wall components of Spirillum putridiconchylium. Journal of Ultrastructure Research 55, 105-118.

Bingle, W. H., Doran, J. L. \& PaGe, W. J. (1984). Regular surface layer of Azotobacter vinelandii. Journal of Bacteriology 159, 251-259.

Bingle, W. H., Doran, J. L. \& Page, W. J. (1986). Characterization of the surface layer protein from Azotobacter vinelandii. Canadian Journal of Microbiology 32, 112-120.

Bingle, W. H., Whippey, P. W., Doran, J. L., MurRay, R. G. E. \& PAGE, W. J. (1987). Structure of the Azotobacter vinelandii surface layer. Journal of Bacteriology 169 (in the Press).

Boggis, W., Kenward, M. A. \& Brown, M. R. W. (1979). Effects of divalent metal cations in the growth medium upon sensitivity of batch-grown Pseudomonas aeruginosa to EDTA or polymixin B. Journal of Applied Bacteriology 47, 477-488.

BRADFord, M. M. (1976). A rapid and sensitive method for the quantitation of microgram quantities of protein utilizing the principle of protein-dye binding. Analytical Biochemistry 72, 248-254.
Browne, D. T. \& KeNT, S. B. H. (1975). Formation of non-amidine products in the reaction of primary amines with imido esters. Biochemical and Biophysical Research Communications 67, 126-132.

BuCKMire, F. L. A. \& MurRay, R. G. E. (1976). Substructure and in vitro assembly of the outer, structured layer of Spirillum serpens. Journal of Bacteriology 125, 290-299.

Chester, I. R. \& Murray, R. G. E. (1978). Proteinlipid-lipopolysaccharide association in the superficial layer of Spirillum serpens cell walls. Journal of Bacteriology 133, 932-941.

Cotton, F. A. \& Wilkinson, G. (1980). Advanced Inorganic Chemistry: a Comprehensive Text, 4 th edn. New York: Wiley.

DORAN, J. L. (1983). Genetic transformation of Azotobacter vinelandii. $\mathrm{PhD}$ thesis, University of Alberta (National Library - Ottawa, 67258).

EVenberG, D., Versluis, R. \& LUGtenberG, B. (1985). Biochemical and immunological characterization of the cell surface of the fish pathogenic bacterium Aeromonas salmonicida. Biochimica et biophysica acta 815, 233-244.

Fairbanks, G., Steck, T. L. \& Wallach, D. F. H. (1971). Electrophoretic analysis of major polypeptides of the human erythrocyte membrane. Biochemistry 10, 2606-2616.

FISHER, R. J., \& BRILL, W. J. (1969). Mutants of Azotobacter vinelandii unable to fix nitrogen. Biochimica et biophysica acta 184, 99-105.

Greenderg, A. E., Trussell, R. R. \& Clesceri, L. S. (1985). Standard Methods for the Examination of Water and Wastewater. Washington, DC: American Public Health Association.

Haller, I. \& Henning, U. (1974). Cell envelope and shape of Escherichia coli K12: cross-linking with dimethyl imidoesters of the whole cell wall. Proceedings of the National Academy of Sciences of the United States of America 71, 2018-2021.

HANCOCK, R. E. W. (1984). Alterations in outer membrane permeability. Annual Review of Microbiology 38, 237-264.

Hanson, R. S. \& Phillips, J. A. (1981). Chemical composition. In Manual of Methods for General Bacteriology, pp. 338-364. Edited by P. Gerhardt, R. G. E. Murray, R. N. Costilow, E. W. Nester, W. A. Wood, N. R. Krieg \& G. B. Phillips. Washington, DC: American Society for Microbiology.

Hastie, A. T. \& Brinton, C. C. (1979). Isolation, 
characterization and in vitro assembly of the tetragonally arrayed layer of Bacillus sphaericus. Journal of Bacteriology 138, 999-1009.

Irvin, R. T., MacAlister, T. J. \& Costerton, J. W. (1981). Tris(hydroxymethyl)aminomethane buffer modification of Escherichia coli outer membrane permeability. Journal of Bacteriology 145, 1397-1403.

KELETI, G. \& LEDERER, W. H. (1974). 2-Keto-3deoxyoctanoate. In Handbook of Micromethods for the Biological Sciences, pp. 74-75. Edited by G. Keleti \& W. H. Lederer. New York: Van Nostrand Reinhold

Kist, M. L. \& Murray, R. G. E. (1984). Components of the regular surface array of Aquaspirillum serpens MW5 and their assembly in vitro. Journal of Bacteriology 157, 599-606.

Koval, S. F. \& Murray, R. G. E. (1981). Cell wall proteins of Aquaspirillum serpens. Journal of Bacteriology 146, 1083-1090.

Koval, S. F. \& Murray, R. G. E. (1983). Solubilization of the surface protein of Aquaspirillum serpens by chaotropic agents. Canadian Journal of Microbiology 29, 146-150.

Koval, S. F. \& Murray, R. G. E. (1984). The isolation of surface array proteins from bacteria. Canadian Journal of Biochemistry and Cell Biology 62, 11811189.

Koval, S. F. \& Murray, R. G. E. (1985). Effect of calcium on the in vivo assembly of the surface protein of Aquaspirillum serpens VHA. Canadian Journal of Microbiology 31, 261-267.

Labischinski, H., BaRNickel, G., BRadaCzeK, H., Nauaman, D., Rietschel, E. T. \& Geisbrecht, P. (1985). High state of order of isolated bacterial lipopolysaccharide and its possible contribution to the permeation barrier property of the outer membrane. Journal of Bacteriology 162, 9-20.

LAEMMLI, U. K. (1970). Cleavage of structural proteins during the assembly of the head of bacteriophage T4. Nature, London 227, 680-685.

Markwell, M. K., HaAs, S. M., Bieber, L. L. \& TOLBERT, N. E. (1978). A modification of the Lowry procedure to simplify protein determination in membrane and lipoprotein samples. Analytical Biochemistry 87, 206-210.

PAGE, W. J. \& DORAN, J. L. (1981). Recovery of competence in calcium-limited Azotobacter vinelandii. Journal of Bacteriology 146, 33-40.

PAGE, W. J. \& HuYer, M. (1984). Derepression of the
Azotobacter vinelandii siderophore system, using iron-containing minerals to limit iron repletion. Journal of Bacteriology 158, 496-502.

Page, W. J. \& von Tigerstrom, M. (1982). Iron- and molybdenum-repressible outer membrane proteins in competent Azotobacter vinelandii. Journal of Bacteriology 151, 237-242.

Rachel, R., Engel, A. \& Baumeister, W. (1983). Proteolysis of the major cell envelope protein of Deinococcus radiodurans remains morphologically latent. FEMS Microbiology Letters 17, 115-119.

Reithmeier, R. A. F. \& Bragg, P. D. (1977). Crosslinking of the proteins in the outer membrane of Escherichia coli. Biochimica et biophysica acta 466, 245-256.

SCHENK, S. P. \& EARHART, C. F. (1981). Characterization of the predominant Azotobacter vinelandii envelope protein. Journal of Bacteriology 146, 398403.

SLeytr, U. B. \& GlauerT, A. M. (1976). Ultrastructure of the cell walls of two closely related clostridia that possess different regular arrays of surface subunits. Journal of Bacteriology 126, 869-882.

Sleytr, U. B. \& Messner, P. (1983). Crystalline surface layers on bacteria. Annual Review of Microbiology 37, 311-339.

Smit, J., Grano, D. A., Glaeser, R. M. \& Agabian, N. (1981). Periodic surface array in Caulobacter crescentus: fine structure and chemical analysis. Journal of Bacteriology 146, 1135-1150.

Thorne, K. J. I., Thornley, M. J., Naisbitt, P. \& GLAUERT, A. M. (1975). The nature of the attachment of a regularly arranged surface protein to the outer membrane of an Acinetobacter sp. Biochimica et biophysica acta 389, 97-116.

Thorne, K. J. I., Oliver, R. C. \& Glauert, A. M. (1976). Synthesis and turnover of the regularly arranged surface protein of Acinetobacter sp. relative to other components of the cell envelope. Journal of Bacteriology 127, 440-450.

Unwin, P. N. T. \& EnNis, P. D. (1984). Two configurations of a channel-forming membrane protein. Nature, London 307, 609-613.

UZgiris, E. E. \& Kornberg, R. D. (1983). Twodimensional crystallization technique for imaging macromolecules, with application to antigen-antibody-complement complexes. Nature, London 301, 125-129. 